ACTA THERIOLOGICA

Vol. 21, 5: 101-116, 1976

\title{
Food Habits of Moose from Augustów Forest
}

\author{
Krzysztof MOROW
}

\begin{abstract}
Morow K., 1976: Food habits of moose from Augustów Forest. Acta theriol., 21, 5: 101-116. [With 6 Tables \& 1 Fig.].

Food habits of moose during autumn have been determined on the basis of analysis of 39 rumen content samples. Trees and shrubs comprise more than $87 \%$ of the diet. The most important species were pine $(51.6 \%)$, trembling aspen, birch, limetree, gray willow, and alder buckthorn. The composition of winter food was identified on the basis of 68,516 bites recorded on shoots in the course of moose tracking. Shoots of trees and shrubs are the most important group of plants in the diet. They comprise more than $99 \%$ of diet during this season. Among trees pine is the most important species $(92.6 \%)$, gray willow and alder buckthorn occupying the first position among shrubs. Daily food consumption in winter was calculated as a result of tracking. Cows consume on average $19.5 \mathrm{~kg}$ of fresh twigs, calves $-17.0 \mathrm{~kg}$, and bulls $-16.0 \mathrm{~kg}$.

[Forestry Res. Inst., 02-362 Warszawa, Wery Kostrzewy 3, Poland]
\end{abstract}

\section{INTRODUCTION}

An increase in moose numbers during recent years and the extension of their range in certain regions of the country brought about serious damage in pine regeneration ( $\mathrm{M}$ orow, 1974). This problem starts to acquire economic importance in forest management. Moose expansion and occupation of ever new ecological niches by them inclines to the question what an impact on primary production is exerted by big ungulates in places of their existence.

The rapid increase in moose numbers in this country took forest and wildlife management unaware. No management quidelines were developed for the species, there were also no basic research on moose biology and ecology.

The literature abounds with papers on moose diets. And so, e.g. Peters on (1955) in his monograph presented results of studies on diet composition and food habits of moose in North America, Skuncke (1949), Hagen (1958, 1962), Koivisto (1963), Loisa \& Pulliainen (1968), Andersson (1971) studied the diet of moose in Scandinavia. In USSR more detailed studies on moose diets were carried out in tundra and taiga (Knorre, 1959; 1959a) and a complete review of Soviet literature under this line is given by Heptner \& Nasimovi č (1967).

Peterson (1955), Danilov (1958), and Heptner \& Nasimovič (1967) indicate that food of moose consists of plants of several hundreds of species, ne- 
vertheless the basic food within individual portion of range is secured by plants of 25-30 species. Characteristic, that along with an increasing fertility of sites and richness of vegetation, increases also the diversity of moose food. Hence the importance of local studies on their diets.

In Poland until now there were no studies on moose diet and certain remarks are contained in only two papers (Anonymous, 1820; Korsak, 1934).

The purpose of the present work was to investigate the composition, quantity, and variation of the food taken during autumn and winter seasons. These seasons of year were selected, because moose feed then mainly on browse, causing most severe damage in forest management.

The food carrying capacity of individual habitats occupied by mose in the Augustów Forest was also tentatively appraised.

\section{CHARACTERISTICS OF THE STUDY AREA}

Studies were carried out in the Augustów Forest (north-eastern Poland, $53^{\circ} 40^{\prime}-$ $-54^{\circ} 10^{\prime},-22^{\circ} 40^{\prime} 23^{\circ} 32^{\prime}$ ) with the area of more than 14.8 thous. ha. Organic soils prevail there. They are classed to the section of hydromorphic soils with all classes included. Climatic conditions are characteristic by a low mean annual temperature $\left(6.1^{\circ} \mathrm{C}\right)$, short vegetation season (192 days), long period of snow cover prevalence (104 days). Annual amplitude of temperature, which is to some degree a measure of continental character of climate amounts to $23^{\circ} \mathrm{C}$.

On the background of above described natural conditions forest site types presented in table 1 were formed. Forest stands consist of: pine $-74 \%$, alder $-10.1 \%$, birch $-9.4 \%$, spruce $-6.2 \%$, and oak, ash, trembling aspen, and limetree - jointly $0.3 \%$. As one can note pine is the dominant species in stands. It forms rather considerable percentage of stands even in untypical for this species sites (fresh and moist deciduous forest). Great per cent of area under alder and birch attracts one's attention.

\section{STUDY PROCEDURE}

Composition of diet, its variation and food selection, were studied with the aid of the analysis of rument content samples and tracking in snow after animals during feeding.

\section{Analysis of Rumen Content Samples}

Samples (39) have been taken from moose harvested in the course of hunting season (September 1 - November 30) during years 1971-1973. Four samples were taken in February and March of 1972. Samples consisting of subsamples taken manually from various portions of rument have been placed in a container with 1 litre volume and flooded with $10 \%$ aqueous solution of formalin. The remaining content of rumen has been measured with 11 dish and recorded on a card together with date and place of kill, sex and age of moose, its weight before and after dressing, weight of internal organs (lungs, heart, liver, and kidneys), and weight of kidney and intestinal fat separated manually.

In laboratory samples have been placed on soil sieves with $2 \mathrm{~mm}$ diameter mesh and rinsed under tap water. The fraction, which passed sieves, was classed 
as unidentifiable remainder (Dzięciolowski, 1970). The portion of sample, which was retained by sieves, has been segregated and identified in a wet state under binocular with $5 \times$ magnification. Following to identification to species or a group of plants, the material has been dried at the temperature of $70^{\circ} \mathrm{C}$ during 48 hours, its volume being measured and weight determined with the accuracy to $0.01 \mathrm{~g}$.

In numerous cases the identification of plant parts down to species was impossible. Then the material has been classed to one of following groups: 1) trees and shrubs, 2) dwarf shrubs, 3) grasses, sedges, and rushes, 4) bryophytes, 5) pteridophytes, 6) herbaceous plants.

Results were presented in percentages of dry weight and volume.

The high proportion of heather and bark of pine and trembling aspen to be found in certain rumen samples made it possible to calculate the mean weight

Table 1

Comparison of forest area according to forest site types.

\begin{tabular}{lrr}
\hline Forest site type & ha & \multicolumn{1}{c}{$\%$} \\
\hline Fresh coniferous forest & $6,798.70$ & 45.79 \\
Moist coniferous forest & 766.04 & 5.16 \\
Bog conifereous forest & 581.34 & 3.92 \\
Fresh mixed coniferous forest & $1,580.29$ & 10.64 \\
Moist mixed coniferous forest & $1,007.56$ & 6.79 \\
Mixed deciduous forest & 707.12 & 4.79 \\
Fresh deciduous forest & 81.87 & 0.55 \\
Moist deciduous forest & 117.03 & 0.79 \\
Ash alderwood & $1,092.66$ & 7.37 \\
Alderwood & 2114.93 & 14.24 \\
Total & $1,4847.54$ & 100.00
\end{tabular}

of these food classes. And so, $50 \mathrm{~cm}^{2}$ of peeled pine bark weighs $2,400 \mathrm{~g}$ (standard deviation $\delta \pm 0.410 \mathrm{~g}), 50 \mathrm{~cm}^{2}$ of peeled aspen bark $-2,962 \mathrm{~g}(\delta= \pm 0.058 \mathrm{~g})$, and 10 twigs of heather $-0.182 \mathrm{~g}(\delta= \pm 0.027)$.

\section{Examination of Feeding Places with the Aid of Tracking in Snow}

The most reliable and abundant data may be secured while using this technique. It permits also to evaluate preferences and diurnal consumption of food.

The procedure is following. A fresh track of moose or moose group has been undertaken and followed. In spots of feeding plant species on which moose fed and quantities of consumed plant parts have been recorded in observation cards. Each bite was accepted as one observation. The material collected included 68,516 bites. During the winter of 1971/1972 also the diameter of each bite was measured. Date and atmospheric conditions were also recorded in observation cards. The length of track in each habitat, number of bedding places, and number of pellet groups were also plotted on a sketch and a map of plant associations.

On the basis of 1000 measurements of diameter at browse point the mean diameter at browsing was determined for shoots of: pine, trembling aspen, birch, gray willow, alder buckthorn, whortleberry, and juniper (100 shoots). Samples of 1000 shoots with definite diameter were taken and the mean weight, volume, and 
Table 2

Moose diet during autumn as determined on the basis of 39 rumen content samples.

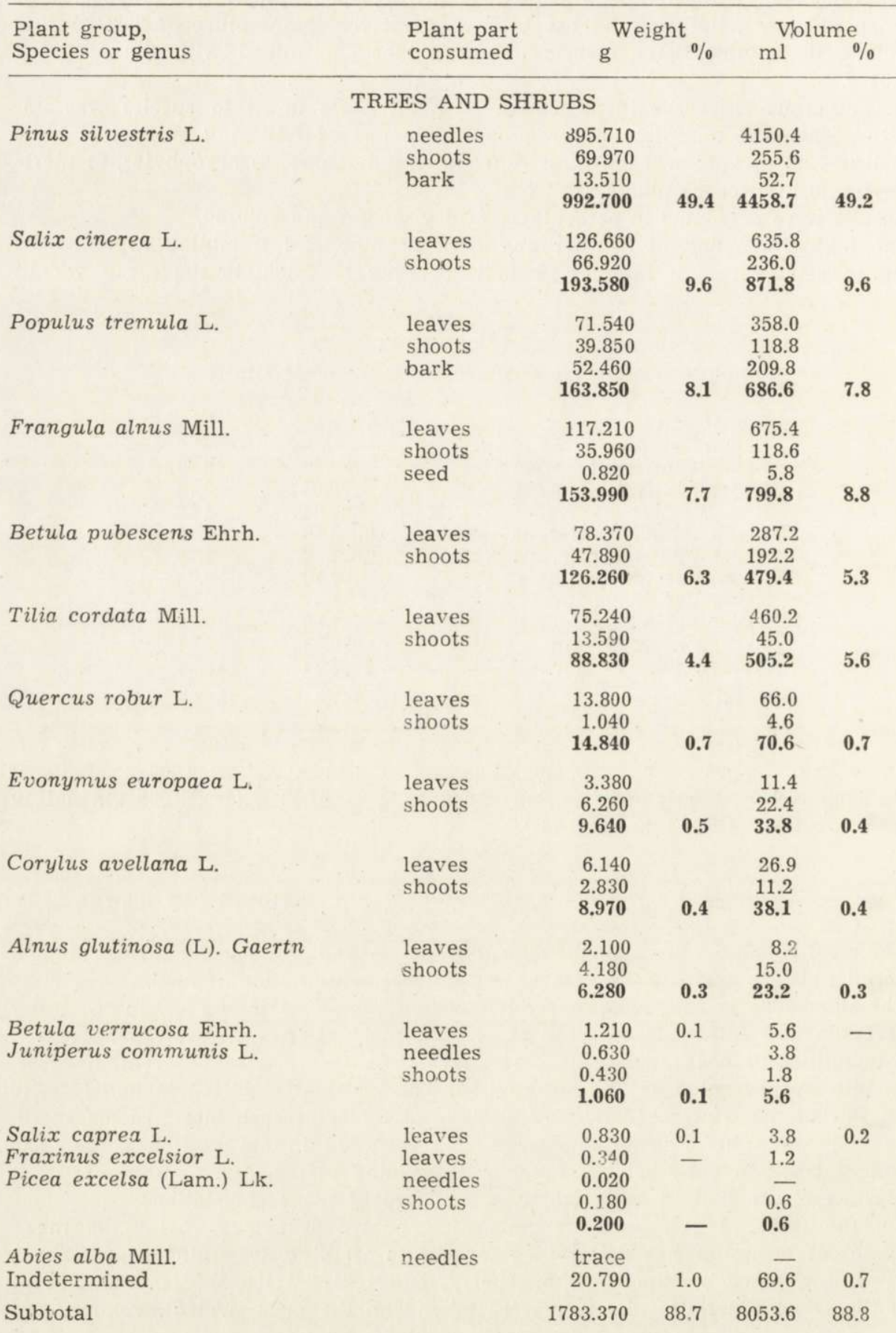


Table 2, concluded.

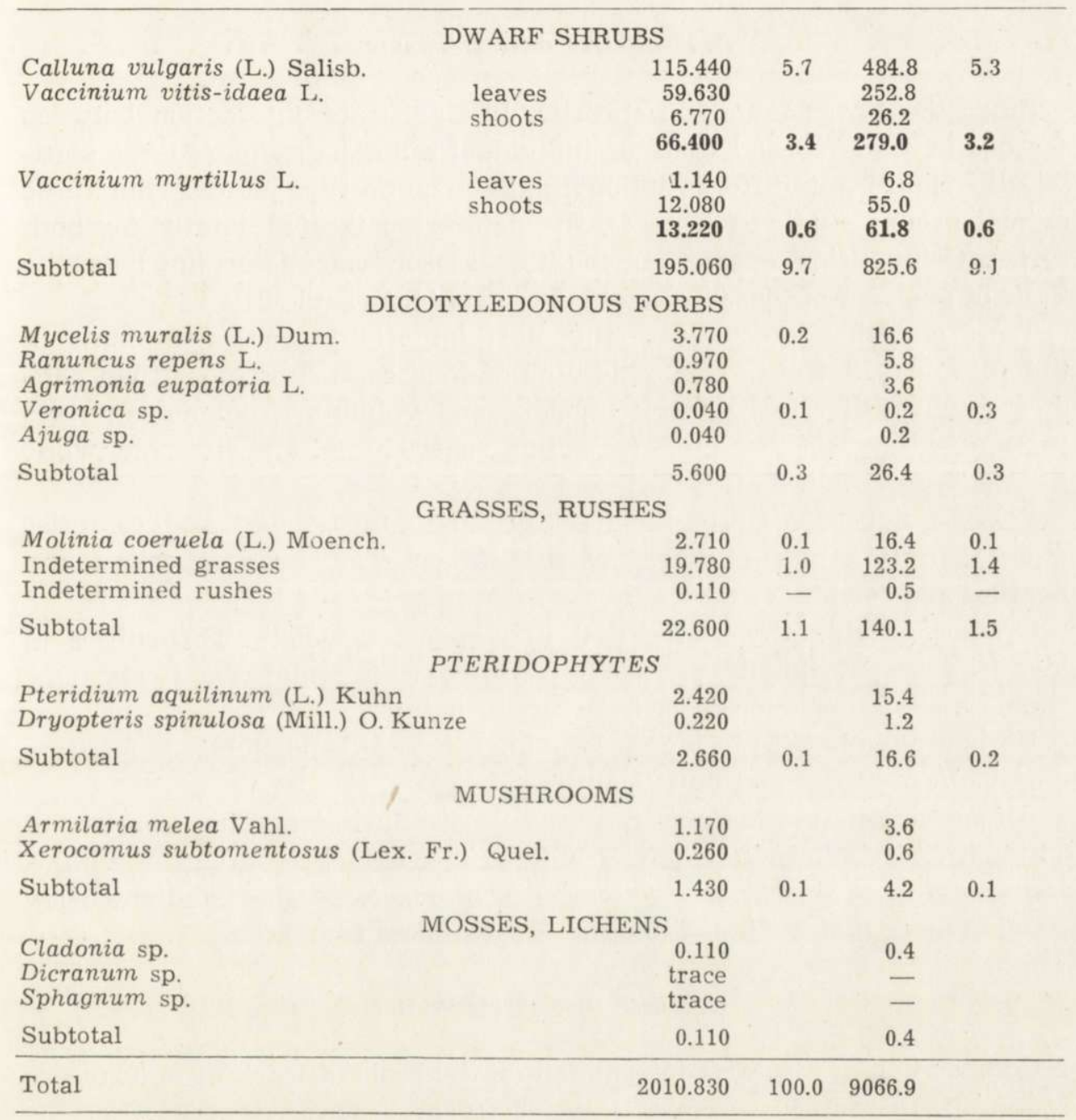

length of shoot (bite) were calculated for definite species. Samples have been taken in various types of habitats, in vicinity of places of the previous feeding of moose.

\section{Statistical Development of Results Concerning Food Relations}

Three animal groups: bulls (32 individuals - 11 rumen samples, 21 trackings), cows (48 individuals - 20 rumen samples, 28 trackings), and calves of both sexes (47 individuals - 12 rumen samples, 35 trackings), two seasons of year (autumn, winter), and 26 species of plants consumed comprising more than $1 \%$ of diet in a sample, were included in analysis. Components of an analysis of variance for 3 directional classification in a non-orthogonal pattern were identified. Calculations were done on electronic digital computer Odra 1204. Table 4 gives results of testing of hypotheses about the effect of individual factors and their interaction. 


\section{COMPOSITION OF MOOSE DIET DURING AUTUMN AND WINTER}

\section{Moose Diet during Autumn}

Since there was found no statistically significant interaction between seasons of year $(S)$ and diets of individual animal groups $(P)$ nor statistically significant differentiation in diet composition among the three animal groups studied (Table 4), the data were treated jointly for both series. Composition of diet during this season was determined on the basis of analyses of 39 samples of rumen content (Table 2).

Trees and shrubs constitute the most important groups of plants in the autumnal diet of moose. This type of food comprises more than $88 \%$ of the whole diet in respect to weight and volume. From among trees the most important are: pine, trembling aspen, birch, and limetree, while in shrub group: alder buckthorn and willow.

Dwarf-shrubs constitute the next group in moose diet and comprise more than $10 \%$ of the weight of food taken. The most important are: heather and cowberry.

Grasses provide $1 \%$ of the diet in respect to weight. Difficulties in identification of this plant group confined it to only two items. One should assume that more species occur in the diet.

Herbaceous plants, pteridophytes, fungi, mosses, and lichens constitute only $0.5 \%$ of moose diet during autumn.

Altogether, moose diet on the study area during autumn consists of 32 identified plant species, out of which nine, namely: pine, gray willow, trembling aspen, birch, alder buckthorn, limetree, heather, and cowberry provide more than $94 \%$ of the bulk of food taken by moose.

\section{Moose Diet during Winter}

Composition of diet was determined on the basis of tracking of 88 moose (Table 3). In the course of tracking 68316 bites were recorded. For the sake of the comparison of results bites were converted into grams of dry matter (see procedure). One bite of pine weighed $3.727 \pm 0.070 \mathrm{~g}$, that of birch $-0.682 \pm 0.030 \mathrm{~g}$, trembling aspen $-0.546 \pm 0.042 \mathrm{~g}$, alder buckthorn $-0.431 \pm 0.035 \mathrm{~g}$, gray willow $-0.361 \pm 0.027 \mathrm{~g}$, juniper $0.217 \pm 0.020 \mathrm{~g}$, while 10 twigs of whortleberry weighed $0.362 \pm 0.042 \mathrm{~g}$.

Shoots of trees and shrubs constitute the most important group of plants in moose diet during winter (they comprise more than $99 \%$ in respect to weight). The most important tree species are: pine, birch, and aspen - comprising $97 \%$. Gray willow and alder buckthorn $(2.5 \%)$ take the first place among shrubs. Dwarf shrubs provide only $0.2 \%$ of moose diet during winter. 
Moose diet during winter (determined on the basis of tracking and analyses of 4 rumen samples) consists of 16 species, among which pine provides $92.1 \%$ in respect to weight.

Table 3

Composition of moose diet during winter as determined on the basis of tracking.

\begin{tabular}{|c|c|c|c|}
\hline Species & No. bites & Wt. (g dry matter) & $\%$ \\
\hline \multicolumn{4}{|l|}{ Trees and shrubs } \\
\hline Pinus silvestris L. & 38,656 & $144,070.9$ & \\
\hline Betula pubescens Ehrh. & 6,415 & $4,373.0$ & 2.8 \\
\hline Salix cinerea L. & 7,235 & $2,611.8$ & 1.7 \\
\hline Populus tremula L. & 3,544 & $1,935.0$ & 1.3 \\
\hline Frangula alnus Mill. & 2,868 & $1,236.1$ & 0.8 \\
\hline Sorbus aucuparia L. & 86 & 58.6 & \\
\hline Juniperus communis L. & 198 & 42.9 & \\
\hline Tilia cordata Mill. & 13 & 8.8 & \\
\hline Evonymus europaea L. & 7 & 5.7 & \\
\hline Padus avium Mill. & 22 & 6.9 & \\
\hline Rubus idaeus L. & 3 & 2.0 & \\
\hline \multirow[t]{2}{*}{ Carpinus betulus L. } & 2 & 1.3 & \\
\hline & & 126.2 & 0.1 \\
\hline Subtotal & 59,049 & $154,355.0$ & 99.8 \\
\hline Dwarf shrubs & & & \\
\hline Vaccinium myrtillus L. & 9,279 & 335.9 & \\
\hline Calluna vulgaris Salisb. & 188 & 3.4 & \\
\hline Subtotal & 9,467 & 335.3 & 0.2 \\
\hline Total & 68,516 & $154,694.3$ & 100.0 \\
\hline
\end{tabular}

\section{Variation in Diet Composition in Relation to Season}

In September trees and shrubs constitute more than $80 \%$ of whole diet in respect to weight. The list consists of: gray willow $-21.9^{0} \%$, limetree $-20.9 \%$, alder buckthorn -16.6 , trembling aspen -11.0 , birch -10.2 , oak -4.5 , and hazel $-2.1 \%$. One should mention that leaves of above mentioned species occupy $90 \%$ of the weight (Fig. 1).

Grasses are consumed by bulls exclusively. Rumen content varies from 7 (bulls) to 25 litres (cows). Quantity of food consumed during this month depends upon sexual activity of animals. Most active bulls take very small quantities of food during a rut and their stomachs contain only grasses, ferns, and soil.

In mid-October moose start to intensity browsing of pine. In certain samples this species occupied more than $80 \%$ of rumen by weight and volume. Generally, pine constitutes $57.2 \%$ of diet during this month. Number of plant species consumed decreases. A high proportion of dwarf shrubs in diet is to be noted. Heather comprises 9.5 , while whortleberry 
$-8.6 \%$ of diet. Leaves constitute only circa $5 \%$ by weight of deciduous species present in samples.

In November pine occupied already $74.3 \%$ of moose diet and the species occurred in all rumen samples. In some samples, shoots and foliage of pine occupied the entire volume of rumen, in certain cases attaining 50 litres. The proportion of trembling aspen is increased $\left(12.6^{0} \%\right)$. Detached bark of trembling aspen and pine occurs in rumens. The proportion of dwarf shrubs is decreased in diet (heather 6.4 and whortleberry $0.7 \%$ ).

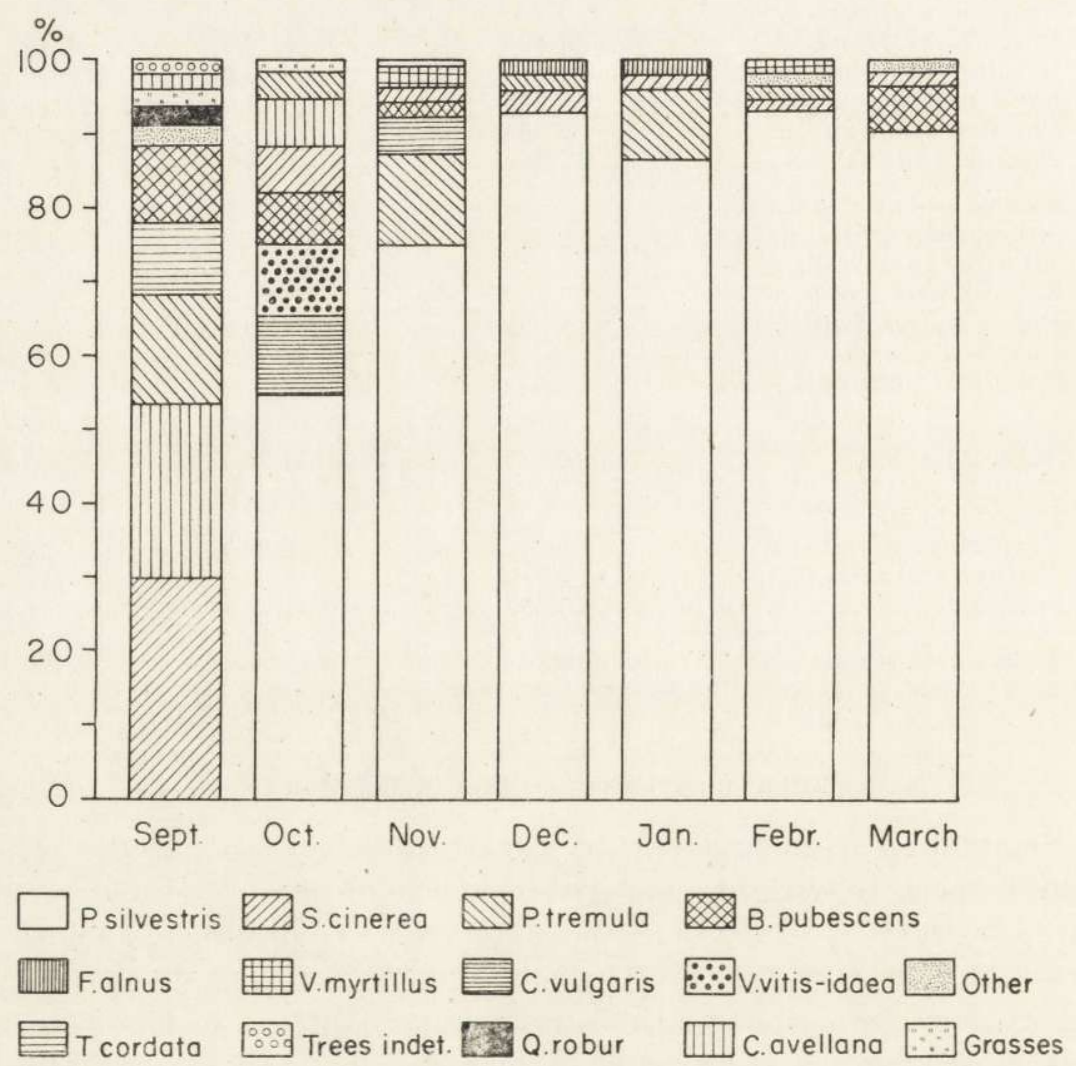

Fig. 1. Variation of diet during individual months of the autumn and winter seasons.

September food composition was based on analyses of 10 rumen samples, for October - 18, November - 11, December diet was based on 3,333 bites, January on 11,902, February - 20,062 bites and analyses of 2 rumen samples, and March diet on 33,219 bites and analyses of 2 rumen samples.

In December pine constitutes more than $92 \%$ of diet by weight. The proportion of trembling aspen declines. Gray willow and alder buckthorn occupy 2.7 and $2.0 \%$ of diet by weight, respectively. 
In January pine occupies $85.3 \%$ of diet by weight. The high proportion of shoots and bark of trembling aspen $(9.7 \%)$ in moose diet attracts one's attention. Shoots of whortleberry take $1 \%$ of diet.

In February pine attains its highest level in moose diet according to weight $(96.3 \%)$. During this month greatest amounts of detached bark

Table 4

Results of testing of hypothesses.

\begin{tabular}{|c|c|c|c|c|}
\hline Variation & $\begin{array}{l}\text { Sums of } \\
\text { squares }\end{array}$ & $\begin{array}{c}\text { Degrees } \\
\text { of freedom }\end{array}$ & $S^{2}$ & $F$ \\
\hline $\begin{array}{l}\text { Tree-way biased classification } \\
\text { Error } \\
\text { General }\end{array}$ & $\begin{array}{l}427690.17 \\
137347.60 \\
565037.77\end{array}$ & $\begin{array}{l}155 \\
205 \\
360\end{array}$ & 669.99 & \\
\hline \multicolumn{5}{|c|}{ Test of interaction $S \times P$ (season $\times$ animal groups) } \\
\hline $\begin{array}{l}\text { For } i+j \text { from the estimation } \\
\text { of parameters } \\
\text { Interaction seasons groups }(S \times P) \\
\text { »Biased" variation } S \times P\end{array}$ & $\begin{array}{r}111837.54 \\
322.98 \\
112160.52 \\
\end{array}$ & $\begin{array}{l}3 \\
2 \\
5\end{array}$ & 161.49 & 1 \\
\hline \multicolumn{5}{|l|}{ Test for animal groups $(P)$} \\
\hline $\begin{array}{l}\text { Biased for seasons } \\
\text { Unbiased for animal groups } \\
\text { For seasons and animal groups } \\
\text { from the estimation of parameters }\end{array}$ & $\begin{array}{r}110782.91 \\
1054.63 \\
111837.54 \\
\end{array}$ & $\begin{array}{l}1 \\
2 \\
3\end{array}$ & 527.32 & 1 \\
\hline \multicolumn{5}{|l|}{ Test for seasons $(S)$} \\
\hline $\begin{array}{l}\text { "Biased" for animal groups } \\
\text { For seasons (unbiased) } \\
\text { For seasons and animal groups } \\
\text { from the estimation of parameters }\end{array}$ & $\begin{array}{r}2976.55 \\
108860.99 \\
\\
111837.54 \\
\end{array}$ & $\begin{array}{l}2 \\
1 \\
3\end{array}$ & 54130.49 & 162.48 \\
\hline \multicolumn{5}{|c|}{ Test of interaction seasons of year $\times$ species $(\mathrm{S} \times \mathrm{D})$} \\
\hline $\begin{array}{l}\text { For seasons of year and species } \\
\text { from the estimation of parameters } \\
\text { Interaction seasons } \times \text { species } \\
(S \times D) \\
\text { "Biased " variation } S \times D\end{array}$ & $\begin{array}{r}387119.92 \\
29246.53 \\
416366.45\end{array}$ & $\begin{array}{l}26 \\
25 \\
51\end{array}$ & 1169.86 & 1.75 \\
\hline \multicolumn{5}{|l|}{ Test for species $(D)$} \\
\hline $\begin{array}{l}\text { For biased variation of season } \\
\text { of year } \\
\text { Unbiased for species } \\
\text { For seasons of year and species } \\
\text { from the estimation of parameters }\end{array}$ & $\begin{array}{l}110782.91 \\
276337.00 \\
387119.91 \\
\end{array}$ & $\begin{array}{r}1 \\
25 \\
26\end{array}$ & 11053.48 & 16.50 \\
\hline \multicolumn{5}{|c|}{ Test for interaction species $\times$ animal groups } \\
\hline $\begin{array}{l}\text { For species and animal groups } \\
\text { from the estimation of parameters } \\
\text { Interaction species } \times \text { animal } \\
\text { groups } P \times D \\
\text { Biased variation } P \times D\end{array}$ & $\begin{array}{r}370221.49 \\
6405.10 \\
376626.59\end{array}$ & $\begin{array}{l}27 \\
50 \\
77\end{array}$ & 128.10 & 1 \\
\hline
\end{tabular}


of pine are to be found. The proportion of trembling aspen in diet drops remarkably. Gray willow and alder buckthorn comprise $2 \%$.

In March pine takes $93.1 \%$ of diet. Until mid-March pine in certain cases was meeting $100 \%$ of the daily food demand. Since mid-March the proportion of birch in diet increases. Generally, birch constitutes $5 \%$ of the March diet of moose.

Statistical analysis (Table 4) indicated seasonal variation $(S)$ in food selection and highly significant dfferentiation in the selection of food plants $(D)$ during the seasons of year studied.

\section{DAILY CONSUMPTION OF FOOD DURING WINTER}

Table 5 illustrates the daily consumption of food by moose during winter. Cows take most food ( $3.95 \mathrm{~kg}$ of dry matter) during day and night, calves consume $3.39 \mathrm{~kg}$ of browse and bulls $-3.11 \mathrm{~kg}$. Pine

Table 5

Daily consumption of food during winter in $\mathrm{g}$ of dry matter

\begin{tabular}{lrrr}
\hline Species & Bull (15) & Cow (18) & Calf $(24)$ \\
\hline Pinus silvestris & $2,760.6$ & $2,714.3$ & $2,335.0$ \\
Betula pubescens & - & 796.8 & 658.1 \\
Populus tremula & 144.7 & 212.9 & 198.7 \\
Salix cinerea & 95.0 & 85.1 & 78.5 \\
Frangula alnus & 78.4 & 104.8 & 63.6 \\
V. myrtillus & 39.8 & 36.6 & 59.3 \\
Total & $3,118.5$ & $3,950.5$ & $3,393.2$ \\
\hline
\end{tabular}

constitutes $85 \%$ of the diet of bulls, $68.7 \%$ - in cows, and $68.8 \%$ in calves, what after conversion amounts to $15.5 \mathrm{~kg}, 15.2 \mathrm{~kg}$, and $13.1 \mathrm{~kg}$ of fresh shoots per day and night, respectively.

\section{FOOD PREFERENCES OF MOOSE DURING WINTER}

Research results indicate that one cannot agree with assumptions of certain researchers, who suggest that the consumption of conifers (pine under our conditions) by moose during winter is of compulsory nature. Pine provides a preferred by moose winter food on sites of cowberry, moor grass, whortleberry, eagle fern types of coniferous forest and in moist mixed coniferous forest. Numerous observations of moose feeding grounds in these associations indicated that this species is a prime browse in relation to gray willow and alder buckthorn. In numerous cases the daily diet of moose consisted of shoots and foliage of pine. Pine bark is being stripped most willingly in the cowberry-type coniferous forest. 
Gray willow, alder buckthorn, and trembling aspen provide a second rate winter food in moose diet on above mentioned sites. On sites of bog bilberry-type coniferous forest, alder marsh, alderwood, and pine-spruce mixed fresh coniferous forest those plants are more willingly taken than pine.

In January aspen bark is a more preferred food than shoots of this species. Trembling aspen is being debarked most willingly in alderwood.

Whortleberry and birch are seasonally preferred food by moose. When the depth of snow cover permits the grazing of whortleberry twigs, it is sometimes more willingly grazed on sites of bog bilberry and moor grass-types of coniferous forest than pine, gray willow, and alder buckthorn. Birch may be considered as a species reluctantly consumed during winter and sometimes even avoided. It is only in late March when birch is intensively browsed and preferred sometimes above pine, gray willow, and alder buckthorn.

\section{DISCUSSION}

\section{Composition of Moose Diet during Autumn and Winter}

Studies carried out in North America (P e t e r s o n, 1955), Europe, and the Asiatic portion of the USSSR (S a in i o, 1955; L o is a \& P u 11 i a inen, 1968; Dinesman, 1959; T im of e eva, 1965; Petrovskij, 1967) indicated high regional and seasonal variation in moose diet. On the basis of an analysis of papers describing moose diet on the territory of USSR (e.g. K a pla nov, 1948; D a nilov, 1958; F ed os ov, 1959; Knorre, 1959; 1959a; Us tinov, 1964 ; Č ervonny j, $1967 ; \mathrm{H}$ e ptner \& Nasimovič, 1967; Chodašova \& Eliseeva, 1970; I va nter, 1970) it was determined that moose consume plants of 355 species, cultivated plants excluding.

From the above data it results that along with an increase in abundance and diversity of vegetation (in the direction from north to south) there increases also the number of plant species in moose diet. Moose are opportunists in feeding, i.e. they eat whatever available.

Only about 40 plant species are basic in moose diet according to above mentioned authors. While analyzing the composition of diet during individual seasons those authors arrive at the conclusion that the division of food plants into exclusively winter and exclusively summer ones does not hold true. It is only the degree of utilization of individual species that varies due to changes in palatability, and mostly in availability of food.

Results characterizing the composition of moose diet in the Augustów Forest obtained with the use of two techniques (analyses of rumen 
content samples and winter tracking in snow) obviously deviate from data secured by above mentioned authors. This indicates a high variation in diet, not only seasonal, but also regional one. During autumn and winter seasons the diet in the Augustów Forest consists of 37 species of food plants.

Seasonal variation in food selection by moose manifests itself first of all by the size of individual groups of food plants - trees, shrubs, dwarf-shrubs, herbaceous plants, pteridophytes, and fungi (autumn) and trees, shrubs, and dwarf-shrubs (winter). For, these two seasons certain species are common, e.g. pine, trembling aspen, birch, alder buckthorn, gray willow - although their percentual proportion and consumed portions (foliage, shoots, bark) varies.

\section{Daily Food Consumption during Winter}

Daily consumption during winter in the study area amounts on average for cows - to $19.5 \mathrm{~kg}$, calves - $17.0 \mathrm{~kg}$, and bulls - to $16.0 \mathrm{~kg}$ of fresh shoots (after conversion from dry matter). As one can note, results

Table 6

Daily requirement of moose for food ( $\mathrm{kg}$ of fresh matter)

\begin{tabular}{ll}
\hline Authority & \multicolumn{1}{c}{ Average daily consumption, kg } \\
\hline Andersson (1971) & 7.07 \\
Kaleckij (1967, 1969) & 7.7 (Yearlings); 11.2 (2 years old); \\
& 12.9 (Adults) \\
Knorre (1959) & 10.5 -13.5 \\
Mech (1966) & 12.2 \\
Peterson (1955) & $18.0-22.5$ \\
\hline
\end{tabular}

obtained on the area of the Augustów Forest deviate somewhat from data obtained by other authors (Table 6). It is characteristic that yearling moose on the study area reveal higher food requirement than bulls.

\section{Food Preeferences of Moose during Winter}

Data on food preferences in relation to palatability and availability of food have been obtained in the course of tracking after moose in feeding places. This way of the determination of preferences seems more reliable than those used in other methods. During tracking one can record species composition of vegetation in relation to food plants occurring in a given area and the selection of habitat by moose in order to feed on definite tree and shrub species (M or ow, 1975).

Differences in food selection by moose during winter may be explained by a various biochemical content of shoots of individual species (and even between various shoots within the same species), which seems to 
be dependent upon the degree of insolation and certainly depends upon the quality of soils in various forest types.

In the course of winter tracking of moose it was noted that the insolated browse was more willingly consumed than that grown in shade. In connection with difficulties in moving in dense pine thickets, moose most frequently browse pine shoots near roads, compartment lines, glades, etc., where shots were insolated. When they fed inside thickets, they browsed only leaders and shoots of the upper verticil. Preferring of shoots and foliage of pine on sites of cowberry, moor grass, whortleberry, eagle farn types and in the moist mixed coniferous forest may be explained by the fact that pine (shoots and foliage) has there higher nutritional value and higher palatability than shoots of other tree and shrub species occurring also abundantly on these sites, which are not consumed in such quantities as pine.

Stalfelt (1970, after Markgren, 1969) characterizes moose as »nitrogen collecting species «. Protein level is always higher in juvenile plants or in their young shoots, as well as in insolated food. This can account also for the preference of insolated browse by moose, above that grown under conditions of poorer illumination.

\section{Food Carrying Capacity of Plant Associations for Moose}

While calculating resources of available browse, food demand, and the utilization of natural food by known numbers of animals, one can estimate food carrying capacity of individual habitats occupied by deer. Such studies were carried out for penned moose (e.g. K n or r e, 1959; K ale ckij, 1967, 1969) and therefore results seem to be underestimated, when compared with those obtained in the course of the present work. According to our calculations bull consumes about $320 \mathrm{~kg}$ of dry mater of browse (including $285 \mathrm{~kg}$ of pine) during winter (on average 104 days - duration of snow cover prevalence), cow - $410 \mathrm{~kg}(282 \mathrm{~kg})$, and calf - $350 \mathrm{~kg}(242 \mathrm{~kg})$ - table 5 . In order to calculate the extent of the utilization of available food resources by moose, the browse situated within feeding zone has been appraised (e.g. Din e sman, 1959; K aleckaja, 1959; Nikiforov \& Gibet, 1959; Kozlovskij, 1961 and 1965; Kaleckaja \& Kudinov, 1967). The weight of browse available per area unit was calculated. Results have been compiled in so-called yield tables. The highest number of moose, at which damage in forest management is not caused and good in qualitative respect status of population is maintained is considered as permissible density of moose (Kozlovskij, 1961).

Results of studies by the above authors indicated that when browse resources amounted to no less than threefold demand of moose inhabiting 
the area, the damage inflicted by moose was of no economic significance.

Pine is the most valuable species in our forests and at the same time provides main component of moose diet during winter. D z ięc i ołowski (1971) evaluated, among other things, the current growth of twigs of trees and shrubs situated within the range of feeding by deer. Studies were carried out in 5 forest associations developed on four forest site types prevailing in respect to acreage in this country.

Since on the area of study these forest site types occupy $68 \%$ of area and there are no other data, it was accepted that the pine stand in the I age class produces in the zone up to $3.0 \mathrm{~m}$ (the stratum of moose feeding) on average $6.0 \mathrm{~g}$ of dry matter per $\mathrm{m}^{2}(60.0 \mathrm{~kg} / \mathrm{ha})$. On the study are pine stand in the Ist age class occupies $15.2 \%$ of area, i.e. provides the moose population with circa 135 tons of dry matter of browse. Moose, while utilizing during winter $92.4 \%$ of young plantations and thickets (M or ow, 1975), have access to 125.1 tons of food during that time. Moose start to use intensively pine during the second half of October on the study area. During this month pine occupies $57.2 \%$ of diet and more than $74 \%$ in November. From calculations it results that an individual consumes on average about $370 \mathrm{~kg}$ of dry matter of pine shoots during autumn and winter and the population utilizes circa 30 tons or $1 / 4$ of pine browse resources, what constitutes about $1 / 5$ of the entire bulk of current year growth of a pine stand in the Ist age class. These are serious economic losses. Losses occur at the density of 5.3 individuals per 1000 ha of forest area (circa 27 ha of pine stand in the Ist age class falls to 1 moose) - therefore, this index may be considered too high.

During years of 1969-1970, when the study area was inhabited by $45-60$ moose (3-4 individuals per 1000 ha of forest area - 35-45 ha of pine stands in the Ist age class fell to 1 individual) losses were of no practical importance.

It is suggested, therefore, to consider on average 3-4 individuals per 1000 ha of forest area as a maximum (optimum for forest and wildlife management) moose density in forest management units. This corresponds with $40-45$ ha of pine stand in the Ist age class falling to one moose. The determination of the permissible moose density in forests should not be valid within the entire area of its occurrence. In the face of not uniform moose distribution it is necessary to determine population size for individual forest districts.

The population inhabiting the study area is a young one, which attained a high rate of growth owing to very favourable environmental conditions. Low numbers of red deer, very low number of roe deer and, therefore, a lack of competitors for food may contribute to a further rapid increase 
in moose numbers. Then the damage caused by moose will become even more severe.

\section{REFERENCES}

1. Anderss on E., 1971: Havaintoja hirven talvisesta ravinnonkäytösta ja vuokansirytmistä. Suomen Riista, 23: 105-118.

2. Anonymous, 1820: Monografia łosia. Sylwan, 1: 27-84.

3. Chodašova K. S. \& Elis e ev a V. I., 1970: Rol' pozvonočnyh životnyh - potrebitelej vetočnyh kormov $\mathrm{v}$ krugovorote zolnyh elementov (na primere lesostepnyh dubrav). [In: Sredoobrazujuščaja dejatel'nost životnyh.] Izd. Mosk Univ.: 52-53. Moskva.

4. Červonnyj V. V., 1967: Ob ekologii, lesohozjajstvennom značenii i promysle losja na Karelskom perešejke. Biologija i promysel losja, 3: 177-188.

5. Danilov D. N., 1958: Osnovnyje kormovye rastenija promyslovyh zverej i ptic. Zool. Žurn., 37, 8: 1205-1213.

6. Dinesman L. G., 1959: Vrednaja dejatelnost kopytnyh v leshozah SSSR. Soob. Inst. Lesa, 13: 5-24.

7. Dzięciołowski R., 1970: Foods of the red deer as determined by rumen content analyses. Acta theriol., 15, 6: 89-110.

8. Dzięci ołowski R., 1971: Sytuacja troficzna populacji jeleni w zależności od warunków środowiskowych. Pr. Inst. Bad. Leśn.

9. F e d o s ov A. V., 1959: Materialy o vlijanii losej na lesovozobnovlenie v Brjanskoj oblasti. Soob. Inst. Lesa, 13: 80-88.

10. H a g e n Y., 1958: Orientering om păbegynte undersökelser over vinternaeringen hos elg og rădyr i Norge. Rep. Norv. St. Game Res. Inst. (mimeo).

11. H a g e n Y., 1962: Hva lever av Elgen i Norge, Oslo: 62-78.

12. Heptner W. G. \& Nasimovič A. A., 1967: Der Elch. Die Neue Brehm Bucherei: 1-231. Ziemsen Verlag, Wittemberg.

13. I v a n te $\mathrm{r}$ E. V., 1970: Izbiratelnost $\mathrm{v}$ zimnem pitanii losja i ee vlijanie na formirovanie i strukturu drevostoev. [In: "Sredoobrazujuščaja dejatel'nost životnyh"]. Izd. Mosk. Univ.: 32-35. Moskva.

14. K a le c k a a M. L., 1959: Povreždenija losem sosnovyh molodnjakov v Darvinskom zapovednike. Soob. Inst. Lesa, 13: $63-69$.

15. Kaleckaja M. L. \& Kudinov K. A., 1967: Formirovanie sosnovyh nasaždenij iz gustnyh molodjakov, povreždennyh losiem. Biologija i promysel losja, 3: 189-215.

16. Ka le ckij A. A., 1965: Rastitelnye korma losjat v letne-osennyj period. Biologija i promysel losja, 2: 113-135.

17. Kaleckij A. A., 1965: Juvenalnaja linka losjat, ee svjaz z sutočnym potrebleniem kormov i izmereniem vesa životnyh. Biologija i promysel losja, 2: $281-285$.

18. Kaleckij A. A., 1967: Korma losej v zimnij priod i obščegodovoj obem potreblenija kormov. Biologija i promysel losja, 3: 221-237.

19. Kaleckij A. A., 1969: Skolko est los. Ohota i ohotn. hoz., 5: 18-19.

20. K a p 1 a n o v L. G., 1948: Los v Sihote-Alinskom zapovednike. Materialy k pozn. fauny i flory SSSR. Novaja serija, Zool, 29: 79-128.

21. Knorre E. P., 1959: Ekologija losja. Tr. Pečoro-Ilyčsk. gos. zapov. 7: 5-122.

22. Knorre E. P., 1959a: Sezonnye osobennosti v kormovom režime losej pečorskoj tajgi. Soob. Inst. Lesa, 13: 70-73. 
23. Koivisto I., 1963: Hirvikantamme rakenteesta, lisääntymisestä ja verotuksesta. Suomen Riista, 16: 7-22.

24. Korsak W., 1934: Łoś w Polsce. Państwowa Rada Ochrony Przyrody, 40: 1-47. Warszawa.

25. Kozlovskij A. A., 1961: Regulirovanie čislennosti losej v lesu. Puškino.

26. Kozlovskij A. A., 1965: Zaščita lesnyh nasaždienij ot povreždienij losjami. Voprosy ohotničego hozjajstva SSSR: $69-74$. Moskva.

27. Loisa K. \& Pulliainen E., 1968: Winter food and movements of two moose in northeastern Finland. Ann. Zool. Fenn., 5: 220-223.

28. M a rkgren G., 1969: Reproduction of moose in Sweden. Viltrevy, 6: 125-299 .

29. Mech L. D., 1966: The wolves of Isle Royale. U.S. Nat. Park. Serv., Fauna Ser. 7: $1-210$.

30. M o r ow K., 1974: Szkody powodowane przez łosie w gospodarstwie leśnym. Sylwan, 118, 6: 38-43.

31. Morow K., 1975: Moose population characteristics and range use in the Augustów Forest. (in press).

32. Nikiforov L. P. \& Gibet L. A., 1959: Vozdejstvie losja na vozobnovlenie sosny v Karelii. Soob. Inst. Lesa, 13: 58-62.

33. Peterson R. L., 1955: North American Moose: 1-280. University of Toronto Press, Toronto.

34. Petrovskij J. T., 1967: Zimnee pitanie losej v lesach Belorusskogo Poozera. Biologija i promysel losja, 3: 238-247.

35. S a in io P., 1955: Hirven talvisesta ravinnosta. Silva Fennica, 88: 1-24.

36. Skuncke F., 1949: Algen: studier, jakt och vărd. 1-420. Stockholm.

37. Timofeeva E. K., 1965: Pitanie i lesochozjajstvennoe značenie losja na severe-vostoke Leningradskoj oblasti. Biologija i promysel losja, 2: 136-158.

38. Ustinov S. K., 1964: Nekotorye voprosy biologii losja Barguzinskogo Hrebta. Biologija i promysel losja, 1: 151-155.

Accepted, June 14, 1975.

\section{Krzysztof MOROW}

\section{ZWYCZAJE POKARMOWE ŁOSI W PUSZCZY AUGUSTOWSKIEJ}

\section{Streszczenie}

Badania prowadzono na terenie Puszczy Augustowskiej w latach 1971-1973, używając dwóch metod w celu ustalenia składu pokarmu - analizy zawartości próbek żwaczy i zimowych tropień żerujących zwierząt.

Lista florystyczna pokarmu losia w okresie jesienno-zimowym na terenie badań składa się z 37 gatunków, w tym: 13 drzew, 6 krzewów, 3 krzewinek, 5 roślin zielnych, 1 trawy, 1 situ, 2 paproci, 3 grzybów, 3 mchów.

Stwierdzono wyraźną zmienność sezonową w składzie pokarmu łosi (Rys. 1). Dieta łosi w okresie jesieni (Tab. 2) składa się z 32 oznaczonych gatunków roślin, z których 9 (w kolejności malejącego znaczenia): sosna, łoza, osika, brzoza, kruszyna, lipa, wrzos, borówka czarna i dąb stanowią najważniejszą grupę roślin w pokarmie łosi. Zajmują one ponad $94 \%$. 